\title{
Quantifying the Growth of Continental Crust through Crustal Thickness and Zircon Hf-O Isotopic Signatures
}

\author{
YUJIAN WANG ${ }^{1}$, DICHENG ZHU ${ }^{1}$, FANGYANG HU ${ }^{2}$ AND \\ JINGAO LIU ${ }^{1}$ \\ ${ }^{1}$ China University of Geosciences (Beijing) \\ ${ }^{2}$ Institute of Geology and Geophysics, Chinese Academy of \\ Sciences \\ Presenting Author: YujianWang@cugb.edu.cn
}

Accretionary orogens act as major sites of generation of continental crust but the growth model of continental crust remains poorly constrained. The Central Asian Orogenic Belt (CAOB), as one of the most important Phanerozoic accretionary orogens on Earth, has been highly debated in terms of the net volume of juvenile crust from being surprisingly high to very low. Using published geochemical and zircon $\mathrm{Hf}-\mathrm{O}$ isotopic datasets of three belts in the Eastern Tianshan terrane of the southern $\mathrm{CAOB}$, we first explore the variations of crustal thickness and isotopic compositions in response to the tectonomagmatic activities with time. Our study clearly delineates that syn-collisional episode experienced a significant mantle-derived crustal growth, attributing to the crustal thickening at the extents of approximately $15 \mathrm{~km}, 10 \mathrm{~km}$, and $20 \mathrm{~km}$ for each belt. Steady progression to radiogenic zircon $\mathrm{Hf}$ isotopic signatures associated with syn-collisional crustal thickening indicates enhanced input of mantle-derived material, which predominantly contributes to the vertical growth of the continental crust. Given the surface areas and relative increases of crustal thickness as the proxies of magma volumes, together with the calculated mantle fraction of the mixing flux, we then are able to evaluate a volume of ca. 39\% juvenile crust formed in the CAOB during the Paleozoic. A crustal growth rate of $0.326 \mathrm{~km}^{3} / \mathrm{y}$ is hence calculated given a lifespan of $255 \mathrm{Ma}$ for the CAOB. This study highlights the validity of using crustal thickness and zircon isotopic signals of magmatic rocks in quantifying the volume and growth rate of juvenile crust in complex accretionary orogens. Our work depicts relatively low growth rates during the Phanerozoic of the global continental crust and its episodic generation pattern that was likely related to the assembly of supercontinents. 